\section{Day-neutral Strawberry Production for Season Extension in the Midsouth}

\author{
James R. Ballington', Barclay Poling, ${ }^{2,4}$ and Kerry Olive ${ }^{3}$ \\ Department of Horticultural Science, North Carolina State University, \\ Campus Box 7609, Raleigh, NC 27695-7609
}

Additional index words. strawberry plasticulture, row covers, income potential, Fragaria xananassa

\begin{abstract}
Until recent years, there have been few attempts in the midsouth to evaluate alternative types of strawberries (e.g., day-neutrals); alternative cultural systems (e.g., tunnel culture); or specific products (e.g., rowcovers) that could be used for either season extension and/or off-season production. In the early $2000 \mathrm{~s}$, research was undertaken to evaluate day-neutral (DN) strawberry production in higher elevations in western North Carolina for harvest in the summer and fall. The effect of DN cultivar, plastic mulch color, planting dates, and plant types was studied in at the Upper Mountain Research Station, Laurel Springs, NC (elevation $914 \mathrm{~m}$ ) over several seasons. In the 2004 season, the DN 'Everest' had yields of nearly $1 \mathrm{~kg} / \mathrm{plant}$ on white plastic mulch using plugs transplanted in late Sept. 2003. However, $\approx 95 \%$ of 'Everest's' production occurred in July and August, when U.S. strawberry prices to growers in wholesale fresh markets have averaged $\$ 1.32$ and $\$ 1.68 \mathrm{~kg}$, respectively (2001 to 2005). Assuming a production level of $\approx 1 \mathrm{~kg} / \mathrm{plant}$, market prices above $\$ 2.48 \mathrm{~kg}$ (breakeven cost) will be needed to make day-neutral strawberry production in the southern Appalachians a profitable venture. We observed peak periods of heavy production in midsummer and more research is needed to identify cultural strategies with plastic mulches, plant types, and possibly rowcovers to increase fall fruit volumes.
\end{abstract}

There is a growing consumer demand for a year-round supply of fresh high-quality small fruits in North America (Vanden Heuvel, 2006), but not until relatively recent years have there been attempts in eastern regions of the United States (Durner, 1999; Pritts and Kelly, 1995; Takeda, 1999, 2002), and specifically in the midsouth (Fernandez and Ballington, 2003; O'Dell, 1998; Pattison and Wolf, 2007; Straw, 2005), to evaluate offseason (e.g., tunnel or greenhouse production in late fall and winter) or extended-season cropping options (e.g., outdoor summer and early fall day-neutral strawberries).

By way of background, the majority of strawberry producers in the southeastern United States and mid-Atlantic states currently use the annual hill plastic mulch production system known as "strawberry plasticulture" (Poling, 2004, 2008). In North Carolina, strawberries grown in this system are locally marketed (selling by pick-your-own, prepick, roadside stands, and farmers' markets) over a 5 -week period in any one growing area. The peak harvest months are April, May, and early June with the season progressing from the eastern coastal plain areas of the state into the mountains (western portion of the state). The strawberry plasticulture production and marketing system in the midsouth has several

\footnotetext{
Received for publication 11 Mar. 2008. Accepted for publication 17 July 2008 .

${ }^{1}$ Professor.

${ }^{2}$ Professor and Extension Specialist (Strawberries). ${ }^{3}$ Agricultural Research Technician.

${ }^{4}$ To whom reprint requests should be addressed; e-mail Barclay_poling@ncsu.edu
}

important advantages over matted row culture, including earlier and longer harvests, cleaner fruit, and increased quality and yields (Pattison and Wolf, 2007; Poling, 2004).

In 2003, there were an estimated 809 ha of strawberry plasticulture production in North Carolina compared with 11,980 in California and 2,870 in Florida (Poling, 2008). For the period from 2000 to 2003 , average yields per ha in the plasticulture system in North Carolina fluctuated between 22 and 30 $\mathrm{MT} \cdot \mathrm{ha}^{-1}$ (Boriss et al., 2006), or $\approx 590$ to $810 \mathrm{~g} /$ plant (assuming 36.9 thousand plants/ ha with double-row plant beds and spacing in the row of $35.6 \mathrm{~cm}$ and $1.52 \mathrm{~m}$ between rows). Safley et al. (2004) estimated typical production and marketing costs for this system to be $\approx \$ 33,460$ ha. By achieving a marketable yield of only $13.4 \mathrm{MT} \cdot \mathrm{ha}^{-1}$ (364 $\mathrm{g} /$ plant), a slightly positive net return of $\$ 511$ ha $(\$ 207$ per acre) can be achieved with a pick-your-own price of $\$ 1.87 \mathrm{~kg}(\$ 0.85 \mathrm{lb})$ and prepick (ready pick) price of $\$ 3.08 \mathrm{~kg}$ $(\$ 1.40 \mathrm{lb})$ (Safley et al., 2004). However, a grower achieving $22.4 \mathrm{MT} \cdot \mathrm{ha}^{-1}$ (607 g/plant), or $\approx 20,000 \mathrm{lb}$ per acre, could realize a net revenue of $\$ 18,720$ ha $(\$ 7,576$ per acre) (Safley et al., 2004). Although the conventional strawberry plasticulture system provides only 5 weeks of harvest in the spring, it should be recognized that growers are capable of generating average weekly profits of over $\$ 3700$ ha (over $\$ 1,500$ per acre). Assuming yields of $22.4 \mathrm{MT} \cdot \mathrm{h}^{-1}$, production and marketing costs of $\$ 33,460$ ha (BE of $\$ 1.49$ $\mathrm{kg}$ ) and pick-your-own price of $\$ 1.87 \mathrm{~kg}$ $(\$ 0.85 \mathrm{lb})$ and the prepick price of $\$ 3.08 \mathrm{~kg}$ (two-thirds of the marketable yield sold pickyour-own and one-third prepick).
Strawberry plasticultrure growers in the midsouth have achieved some success in advancing the harvest by $10 \mathrm{~d}$ to 2 weeks in the early spring with the use of floating rowcovers applied in midwinter and left on the crop until the early blossom period. However, in most areas of North Carolina, it is difficult to extend harvest beyond the spring season with either short-day (SD) or day-neutral $(\mathrm{DN})$ type strawberries because of warmer temperatures that occur in mid- to late May.

In recent years, there have been a few reports in the literature on strawberry production systems that would potentially allow growers in the midsouth to achieve extended cropping with DN strawberries in the summer (Straw, 2005) and with double-cropping in the off-season (late fall/winter) (Fernandez and Ballington, 2003).

Fernandez and Ballington (2003) have reported for a coastal plain location in North Carolina that conditioned and unconditioned 'Sweet Charlie' plants produced 127 to 175 $\mathrm{g} / \mathrm{plant}$ and 0 to $44 \mathrm{~g} / \mathrm{plant}$, respectively, in unheated high tunnels in the late fall and early winter. At a piedmont location in North Carolina, conditioned plants established on the earliest date averaged $65 \mathrm{~g} / \mathrm{plant}$, whereas those established on the last date only averaged $15 \mathrm{~g} /$ plant (Fernandez and Ballington, 2003). Spring yields from the coastal plain region were lower than the piedmont region. Spring yields ranged from 150 to $350 \mathrm{~g} / \mathrm{plant}$ at the coastal plain site and 200 to $373 \mathrm{~g} /$ plant at the piedmont location.

In reference to the fall and spring production option (double-cropping) with conditioned plugs (Fernandez and Ballington, 2003), Straw (2005) observes that "recovering production costs in the fall" may be an important way to reduce risks associated with annual strawberry plasticulture production. However, despite often high local prices for off-season fruit of $\$ 35$ to $\$ 40$ flat $(8-\times 454-\mathrm{g}$ clamshells) (Straw, 2005), or $\$ 9.67$ to $\$ 11.04$ $\mathrm{kg}$, the double-cropping program has not been adopted by more than a few growers in North Carolina and South Carolina.

In Tennessee, Straw (2005) has investigated the potential of fall fruiting of 'Sweet Charlie' (SD type), along with 2 DN strawberry cultivars (Everest and Seascape) at the Plateau Experiment Station near Crossville, but problems were encountered with wildlife feeding on plants as well heavy and frequent rainfalls at harvest and anthracnose fruit rot.

In the mid-Atlantic region of the United States, Takeda (2002) has investigated outof-season strawberry production and found that plug plants of the SD cultivar Chandler produced 600 to $700 \mathrm{~g}$ of fruit in winter without low-temperature chilling treatment of plug plants. Durner (1999) has also reported on winter greenhouse strawberry production using conditioned 'Sweet Charlie' plug plants. In Virginia, Pattison and Wolf (2007) have evaluated protected culture for season extension and report that a $7.3 \times 60.9$ tobacco greenhouse or high tunnel planted a density of $\approx 10$ plants $/ \mathrm{m}^{2}$ can yield $619 \mathrm{~g} /$ plant 
for an approximate 60 -d period from early March to early May (2006). A marketable yield of $619 \mathrm{~g} /$ plant is comparable to productivity levels reported for strawberry plasticultrure production of from 22 to 30 $\mathrm{MT} \cdot \mathrm{ha}^{-1}$ (Boriss et al., 2006), or $\approx 590$ to $810 \mathrm{~g} /$ plant.

Although fall and winter production of strawberries may be technically feasible (Fernandez and Ballington, 2003), there have not been any economic analyses reported in the literature for alternative production systems in the midsouth. An economic analysis is currently underway for a SARE research project in Pennsylvania and Maryland where Lantz et al. (2008) are evaluating summer harvest of DN strawberry cultivars (Seascape and Everest) in higher elevation areas (Garrett Co., MD, elev. 762 m; and Rock Springs, PA, elev. $457 \mathrm{~m}$ ).

Temperatures exceeding 30 to $32{ }^{\circ} \mathrm{C}$ will often end the spring harvest season by inhibiting further flower bud formation and development. Serce and Hancock (2000) have also indicated that, "A common complaint with day-neutral strawberries is that they perform poorly in mid-summer heat". However, appropriate temperatures for summer and possibly fall production of DNs may occur in a number of areas in the southern Appalachians at 760 to $900 \mathrm{~m}$ and above (Poling and Ballington, 2006), including largely rural areas of western North Carolina where Fraser fir [Abies fraseri (Pursh) Poir] and burley tobacco have provided a major source of income to farmers. With the end of the federal tobacco program in 2004 (Brown, 2005), growers in this region are being challenged to find ways to transition from tobacco into other crops and value-added enterprises.

Developing a profitable DN strawberry plasticulture production and marketing system for tobacco farmers in the southern Appalachians is going to require the talents of small fruit breeders working in concert with growers, nursery producers, cultural workers, plant pathologists, entomologists, and economic and marketing experts. The primary purpose of this research project was to investigate the opportunity for summer and fall strawberry harvest at high elevation sites in the southern Appalachians with promising DN cultivars from California and the United Kingdom. Over the period 2002 to 2004, there were $3 \mathrm{DN}$ strawberry studies conducted at the Upper Mountain Research Station, Laurel Springs, NC (36.4 N, -81.28 W, 914 m elev., and U.S. Department of Agriculture hardiness zone 6a). In addition, we evaluated the effects of plastic mulch color, plant types, and planting dates.

\section{Materials and Methods}

2002 experiment. Transplanting dates in 2002 for cold-stored plants of 4 DN cultivars (Aromas, Diamante, Everest, and Seascape) were on 15 Apr., 1 May, and 15 May. Dormant plants were established on raised beds fumigated with methyl bromide/chloropicrin with either white/black or black plastic mulch using standard plasticulture production methods (Poling, 2004). This initial experiment was replicated only two times in a randomized complete block design arranged in a split-split-plot layout in which the two plastic mulches were assigned to the main plots; the three planting dates were assigned to the subplots; and the four cultivars were assigned to the subsubplots. There were 24 dormant (frigo) plants transplanted per $1.52 \times 3.65-\mathrm{m}$ plot; plant spacing was $30.5 \mathrm{~cm}$ between plants in the row and $30.5 \mathrm{~cm}$ between rows in double-offset rows with drip irrigation buried $5 \mathrm{~cm}$ in the bed middle. The plants were fertigated with $5.6 \mathrm{~kg} \cdot \mathrm{ha}^{-1}$ nitrogen with the beginning of growth and throughout the flowering and fruiting season every 3 weeks. The first flowers (initiated the previous fall) were removed by hand. Floating rowcovers $\left(51 \mathrm{~g} \cdot \mathrm{m}^{-2}\right)$ were used to provide additional protection during cold temperature events in September and October.

2002 to 2003 experiment. The transplanting date in 2002 for plug plants of $3 \mathrm{DN}$ cultivars (Diamante, Everest, and Seascape) was on 30 Oct. Field preparation, plastic mulch (white/black, or black plastic mulch), and plant spacing was the same as in the 2002 experiment. This experiment was replicated three times in a randomized complete block design arranged in a split-split-plot layout similar to the 2002 experiment. There were 30 plugs transplanted per $1.52 \times 4.57-\mathrm{m}$ plot. Unlike the 2002 experiment, first flowers were not removed. The plants were fertigated as in the 2002 experiment. Floating rowcovers $\left(51 \mathrm{~g} \cdot \mathrm{m}^{-2}\right)$ were used to provide overwinter protection as well as for frost events in Sept. and Oct. 2003.

2003 to 2004 experiment. There were two transplanting dates in Fall 2003 (25 Sept. and 23 Oct.) for plug plants of 2 DN cultivars (Everest and Seascape). Field preparation and plastic mulch comparisons (white/black versus black plastic mulch) were the same as previous experiments. This experiment was replicated three times in a randomized complot layout with the two plastic mulches assigned to the main plots; the two planting dates assigned to the subplots; and the two cultivars assigned to the subsubplots. There were 16 plugs transplanted per $1.52 \times 3.65-\mathrm{m}$ plot. Plant spacing was $45.7 \mathrm{~cm}$ between plants in the row and $30.5 \mathrm{~cm}$ between rows in double-offset rows. Similar to the 2002 to 2003 experiment with plugs, first flowers plete block design arranged in a split-split-

were not removed. The plants were fertigated as in the 2002 experiment. Floating rowcovers $\left(51 \mathrm{~g} \cdot \mathrm{m}^{-2}\right)$ were used to provide overwinter protection as well as for frost events in Sept. 2004.

Data analysis. All data for the three experiments was analyzed by Proc GLM (SAS, Cary, NC). Only main effects were statistically important in the Laurel Springs experiments.

\section{Results and Discussion}

Cultivars. 'Aromas' had poor fruit quality and was dropped from testing after the 2002 season. Relatively low productivity of 'Diamante' in both 2002 and 2003 and less desirable fruit quality led to a decision to discontinue further testing of this DN cultivar in 2004 (Table 1). In 2003 and 2004, 'Everest' demonstrated excellent productive potential based on seasonal yields that equaled or exceeded $700 \mathrm{~g} / \mathrm{plant}$ in both years (Table 1). In 2004, 'Everest' marketable yields were nearly $1 \mathrm{~kg} /$ plant, although fruit size fell to $14.5 \mathrm{~g}$ from $19.5 \mathrm{~g}$ in 2003 (Table 1). Unfortunately, 'Everest' fruit quality was rather poor in the initial harvests each year and then gradually improved through the season, but it was never better than average. In contrast, 'Seascape' fruit quality was consistently good throughout the season each year. However, only fair yields were achieved with 'Seascape' in 2003 as a result of unanticipated difficulties encountered in locating disease-free transplants of this cultivar in 2002. More recently, we have evaluated the newer California DN 'Albion' at this same location (Laurel Springs), and in its first season of testing (2007), an average marketable yield of $1.02 \mathrm{~kg} /$ plant was achieved from harvests, which began on 15 May 2007 and lasted until 16 Oct. 2007 (unpublished data). Because of its attractive appearance, firmer texture, and excellent flavor, 'Albion' (a recent release from the University California) appears to be a promising candidate for local marketing in the summer and fall, and we are now increasing our research emphasis on this newer California DN. 'Albion' has significantly better fruit size than 'Seascape', making this cultivar an excellent candidate for "local" fresh market shipping. Chainstore buyers are now requiring clamshell berry counts of 32 or less per 454-g container (personal communication with NC grower-shippers). A 2007 seasonal average berry size of $20.3 \mathrm{~g}$ for 'Albion' represents a 22 versus 28 count for 'Seascape'

Table 1. Marketable yield and fruit size of day-neutral strawberry cultivars, Laurel Springs, NC ${ }^{z}$.

\begin{tabular}{|c|c|c|c|c|c|c|}
\hline \multirow[b]{2}{*}{ Culitvar } & \multicolumn{3}{|c|}{ Marketable yield (g/plant) } & \multicolumn{3}{|c|}{ Fruit size (g/berry) } \\
\hline & $2002^{y}$ & $2003^{x}$ & $2004^{w}$ & $2002^{y}$ & $2003^{x}$ & $2004^{w}$ \\
\hline Aromas & $358 \mathrm{a}$ & & & & $14.2 \mathrm{~b}$ & \\
\hline Diamonte & $217 \mathrm{~b}$ & $335 \mathrm{c}$ & & & $15.1 \mathrm{a}$ & $23.2 \mathrm{a}$ \\
\hline Everest & $430 \mathrm{a}$ & $700 \mathrm{a}$ & $968 \mathrm{a}$ & $13.2 \mathrm{c}$ & $19.5 \mathrm{~b}$ & $14.5 \mathrm{~b}$ \\
\hline Seascape & $427 \mathrm{a}$ & $411 \mathrm{~b}$ & $710 \mathrm{~b}$ & $14.3 \mathrm{~b}$ & $18.1 \mathrm{c}$ & $15.2 \mathrm{a}$ \\
\hline
\end{tabular}

${ }^{\mathrm{z}}$ Mean separation within columns by Waller-Duncan test K-ratio $t$ test $(P<0.05)$.

${ }^{\mathrm{y}}$ Transplanting of dormant plants on 15 Apr., 1 May, and 15 May 2002.

${ }^{\mathrm{x}}$ Transplanting of plug plants on 30 Oct. 2002.

wTransplanting of plug plants on 25 Sept. and 23 Oct. 2003. 
that had average fruit size of $15.8 \mathrm{~g}$ in 2007 (unpublished data).

The marketable yield for 'Seascape' in 2007 of $1.33 \mathrm{~kg} /$ plant (unpublished data) was substantially greater than in 2004 of $710 \mathrm{~g} /$ plant (Table 1), and this may in part be explained by an earlier plug transplanting date in early September (9 Sept. 2006) versus late September and October in Fall 2003. Also, the summer and fall season in 2007 was notable for its near-perfect harvest conditions because virtually no rainfall occurred during the entire production season (mid-May through mid-October).

Plant spacing. Plant spacing was changed from $30.5 \mathrm{~cm}$ between plants in the row to $45.7 \mathrm{~cm}$ for the third season (2003 to 2004). We found that by changing plant spacing from $30.5 \mathrm{~cm}$ between plants in the row to $45.7 \mathrm{~cm}$, we did not experience any adverse effects on productivity per unit area, and the reduced plant crowding at the $45.7-\mathrm{cm}$ spacing benefitted harvest operations. Assuming plug costs of $\$ 0.25$ each, growers could potentially realize a saving in plant costs/ha of more than $\$ 3500$ with the $45.7 \mathrm{~cm} \times 1.52-\mathrm{m}$ spacing.

Plastic mulch. Strawberry DNs have apparently achieved little success in continental climates of the eastern United States as a result of summer temperatures that are frequently high enough to inhibit flower bud formation. Thus, in addition to selecting a high elevation site (greater than $900 \mathrm{~m}$ ) in western North Carolina for testing summer and fall strawberry DN production, we also examined the influence of cooler white plastic mulch film versus black, which is the standard film used in the fall-planted strawberry plasticulture system (Poling, 2004). White mulch on top of black plastic (laminated) appeared to give better production than the black film in 2002 and 2004, but in a cooler season (2003), the black plastic mulch gave higher yields (Table 2).

In our test location, we also observed that DN strawberry crops on white and black plastic have distinctly different harvest peaks during the summer and early fall. As part of on overall economic and market development strategy for DN strawberries, workers in Pennsylvania and Maryland have reported, "Supermarkets have cautioned us that fruit should be available every week of the year and should be produced within 200 miles (321 km)" (Lantz et al., 2008), and Sjulin

Table 2. Effect of mulch color on marketable yield of day-neutral strawberries, 2002 to 2004, Laurel Springs, NC.

\begin{tabular}{lccc}
\hline & \multicolumn{3}{c}{ Marketable yield (g/plant) } \\
\cline { 2 - 4 } Mulch & $2002^{\mathrm{z}}$ & $2003^{\mathrm{y}}$ & $2004^{\mathrm{x}}$ \\
\hline White/black & 407 & 425 & 903 \\
Black & 309 & 538 & 775 \\
Probability > F & 0.002 & 0.003 & 0.016 \\
\hline${ }^{\text {z}}$ Average across & 15 Apr., 1 May, and 15 May 2002 \\
planting dates. \\
y30 Oct. 2002 planting date. \\
xAverage across 25 Sept. and 23 Oct. 2003 planting \\
dates.
\end{tabular}

(2003) has previously identified the value of increasing, "overall summer volume without creating peak periods of heavy volume". Thus, to help producers in the southern Appalachians achieve consistent week-tovolumes of DN strawberries throughout the summer and fall, we plan to continue our investigations of various plastic mulch materials in future trials as well as to evaluate different plant types and planting dates (discussed in the next section) to improve the overall harvest distribution pattern in summer and fall without creating "peak periods of heavy volume" (Sjulin, 2003). It is also noteworthy that our harvest crew did not observe any loss in fruit quality for berries produced on black plastic versus white plastic in any season (Larry Wohlers, Horticultural Crop Technician, UMRS, Laurel Springs, personal communication).

Plant types, planting dates, harvest season length, and distribution. In developing a cultural system for summer and fall DN strawberry production, it is also important to identify reliable sources of DN plant material as well as plant types that will optimize production. In our 2002 investigation, we used dormant stored (frigo) plants that were established on three planting dates. There was a statistically important effect of planting date with dormant-stored plants set on 15 Apr. producing the highest marketable yield of $408 \mathrm{~g} /$ plant (versus $387 \mathrm{~g} /$ plant for 1 May and $279 \mathrm{~g} /$ plant for 15 May). In 2004, DN plug plants established on 25 Sept. 2003 had significantly higher marketable yields than plugs transplanted on 23 Oct. 2003 (957 g/ plant versus $721 \mathrm{~g} /$ plant).

Dormant plant material was not directly compared with plugs in any one season, but it would appear that fall-planted plugs are more productive, because yields of both 'Everest' and 'Seascape' were substantially higher in 2004 (when only plugs were used) than in 2002 (Table 1).

Strawberry plasticulture growers in the southern Appalachians could potentially achieve production in the summer and fall with DN cultivars, and this could be combined with an average 5-week 'Chandler' (SD) season in the spring for as many as $5 \frac{1}{2}$ months of continuous fruiting (May through

Table 3. Monthly prices received by growers for fresh strawberries (dollars $/ \mathrm{kg})^{\mathrm{z}}$ from 2001 through 2005 and 5-year average.

\begin{tabular}{lcccccc}
\hline Month & 2001 & 2002 & 2003 & 2004 & $2005^{\mathrm{y}}$ & Avg. \\
\hline January & 3.99 & 2.56 & 2.40 & 3.33 & 3.06 & 3.07 \\
February & 2.36 & 2.18 & 1.94 & 2.82 & 2.47 & 2.35 \\
March & 1.79 & 1.93 & 1.42 & 1.52 & 1.34 & 1.60 \\
April & 1.67 & 1.32 & 1.53 & 1.16 & 0.99 & 1.33 \\
May & 1.14 & 1.40 & 1.42 & 1.42 & 1.21 & 1.32 \\
June & 1.36 & 1.29 & 1.28 & 1.46 & 1.24 & $1.33^{\mathrm{x}}$ \\
July & 1.52 & 1.17 & 1.47 & 1.31 & 1.12 & $1.32^{\mathrm{x}}$ \\
August & 1.93 & 1.82 & 1.50 & 1.70 & 1.44 & $1.68^{\mathrm{x}}$ \\
September & 1.72 & 1.29 & 1.91 & 2.18 & 1.86 & $1.79^{\mathrm{x}}$ \\
October & 1.78 & 1.51 & 2.20 & 2.20 & 1.87 & 1.91 \\
November & 2.13 & 2.38 & 3.64 & 4.19 & 2.25 & 2.92 \\
December & 2.49 & 3.57 & 3.75 & 3.90 & 1.87 & 3.12 \\
\hline
\end{tabular}

${ }^{2}$ Source: Agricultural prices. National Agricultural Statistics Service, USDA.

${ }^{y}$ Data for 2005 are preliminary.

${ }^{\mathrm{x}}$ Monthly average price used for economic analysis in Table 6 .
mid-October). In 2002, the harvest began on 15 July and continued until the first week of October (22 harvests, semiweekly harvests). It was interesting to note that although planting on 15 April and 1 May (2002) led to earlier production, the harvest peaks for these 15 Apr. and 1 May occurred in August, whereas the peak production for DN material plants established on 15 May occurred in September (data not shown) when wholesale fresh market strawberry prices to growers are generally much higher than earlier in the summer (Table 3 ).

In 2003, we switched to planting plugs in the fall (30 Oct. 2002), and DN harvest began $\approx 3$ weeks earlier (24 June) than the previous year when we used dormant plant material set in the spring. The harvest in 2003 continued until early October ( 24 harvests, semiweekly harvests). In 2004, harvest once again began on 24 June and continued through the first week in September (20 harvests, biweekly harvests). In 2003 and 2004, we observed harvest peaks near the end of July and in early August (data not shown). From a market price standpoint, it would be desirable to modify our production program so that higher production volumes would occur in later summer and early fall when growers could possibly obtain a greater price premium for berries produced in September and October (Table 3).

Economic implications. It is very exciting to think about the potential of growing DN strawberries for summer and fall fruiting in the eastern United States, but it is also critical to remember that profitability ultimately determines whether DN strawberry production is an economically viable enterprise for burley tobacco and other growers in this region of North Carolina seeking an alternative crop. As is often the case in the early stages of work with a new horticultural enterprise, the research is largely from a breeding and cultural perspective (i.e., what are the best cultivars and growing practices?). It is also quite common for most businesses to initially concentrate on creating products and services (supply-side economics) and then at a later stage attempt to stimulate a demand for them (Kash, 2002). An alternative business approach is to first determine what 
current and existing demand exists and then only create products and services to meet that demand. This is also referred to as a marketdriven approach (Poling, 1993). In North Carolina, we have not yet developed an actual budget for summer season DN strawberry production costs and returns nor have we conducted an analysis of the demand for this product. However, it is possible to make some preliminary projections about the costs and returns associated with this system relative to the conventional strawberry plasticulture system with spring season harvest. For example, we can estimate preharvest production costs of $\approx \$ 0.74 \mathrm{~kg}$ (Table 4) based on past economic analysis of strawberry plasticulture production (Safley et al., 2004) and assuming DN marketable yields of $36,450 \mathrm{~kg} \cdot \mathrm{ha}^{-1}$. This assumed production level of $36,450 \mathrm{~kg} \cdot \mathrm{ha}^{-1}(1.27 \mathrm{~kg} /$ plant $)$ represents the highest production level we achieved with the cultivar Everest in 2004 using white/black plastic mulch and 25 Sept. 2003 planting date (data not shown). For the purpose of this preliminary analysis, we assigned costs similar to those experienced by Florida strawberry growers for harvesting, packaging, and marketing of \$1.54 kg (\$0.85 $+\$ 0.69)$, and this would bring our projected total cost per unit to $\$ 2.28 \mathrm{~kg}$ (Table 4), which is significantly higher than the average wholesale market prices paid to U.S. fresh market strawberry growers in the months June, July, August, September, and October (Table 3). One can easily evaluate other production levels as shown in Table 5 to see the impact of total marketable yield on cost per unit $(\mathrm{kg})$ of production (shown in column $f$ ).

Table 4. Preliminary cost analysis for strawberry plasticulture production for summer season production of 'Everest' day-neutral in Laurel Springs, NC, compared with off-season (winter) wholesale market production in Florida ${ }^{\mathrm{z}}$.

\begin{tabular}{lcc}
\hline Item & Florida & $\begin{array}{c}\text { Western North } \\
\text { Carolina }(>900 \mathrm{~m})\end{array}$ \\
\hline Yield/ha $(\mathrm{kg})$ & $23,311^{\mathrm{y}}$ & $36,450^{\mathrm{x}}$ \\
Preharvest cost $/ \mathrm{kg}$ & $\$ 1.18^{\mathrm{z}}$ & $\$ 0.74^{\mathrm{w}}$ \\
Pack and market & $\$ 0.85^{\mathrm{z}}$ & $\$ 0.85^{\mathrm{z}}$ \\
$\quad$ cost $/ \mathrm{kg}$ & & \\
Harvesting & $\$ 0.69^{\mathrm{z}}$ & $\$ 0.69^{\mathrm{z}}$ \\
Total cost $/ \mathrm{kg}$ & $\$ 2.72$ & $\$ 2.28$ \\
\hline
\end{tabular}

${ }^{{ }^{2} \text { Source: University of Florida, IFAS Agriculture }}$ Business Center. Strawberries: Estimated pro duction costs in the Plant City area, 2003-2004. 22 July 2008. <http://strawberry.ifas.ufl.edu/stats20032004.htm>.

${ }^{y}$ Equivalent to 6425 flats/ha (2600 flats/ha) with average weight $3.6288 / \mathrm{kg}$.

${ }^{\mathrm{x}}$ Calculation based on 28.7 thousand plants/ha and avg. plant yield of $1.27 \mathrm{~kg}$.

${ }^{\text {w}}$ Calculation based on an estimate of $\$ 27,068$ production costs/ha, which represents $\approx 10 \%$ higher cost/ha than the standard North Carolina strawberry plasticulture system (spring production). This difference takes into account a higher cost for day-neutral strawberry plugs of $\$ 0.25$ each, or $\$ 7,175 /$ ha versus $\$ 4,654$ for plugs in the 2004 budget (Safley et al., 2004).
For the 'Everest' treatment that produced $1.27 \mathrm{~kg} / \mathrm{plant}$ in $2004,45 \%$ of the fruit was harvested in July and 49\% was harvested in August (Table 6). Wholesale prices in July and August have averaged $\$ 1.32$ and $\$ 1.68$ $\mathrm{kg}$, respectively (Table 3), and this treatment could potentially have generated yields of $36,450 \mathrm{~kg} \cdot \mathrm{ha}^{-1}$ worth an estimated $\$ 55,151$ ha (Table 6). However, with costs of $\$ 2.28$ $\mathrm{kg}$, or $\$ 83,106$ ha $\left(\$ 2.28 \times 36,450 \mathrm{~kg} \cdot \mathrm{ha}^{-1}\right)$, this would potentially lead to an estimated loss of $\$ 27,955$ ha $(\$ 83,106$ ha to $\$ 55,151$ ha). Under this particular fresh market price scenario, it is not possible to be optimistic about the economics of DN strawberry production, even with yields as high as $1.27 \mathrm{~kg}$ / plant $\left(36,450 \mathrm{~kg} \cdot \mathrm{ha}^{-1}\right)$. Furthermore, based on several years of evaluation of DN cultivars in this region, it would probably be more realistic to use average market yields closer to $\approx 1 \mathrm{~kg} / \mathrm{plant}$ for economic analysis, especially with the cv. Albion, which is approximately one-third less productive than 'Seascape'.

Thus, for season extension with strawberries in summer and fall to be an attractive enterprise at production levels identified through this research project ( $\approx 1 \mathrm{~kg} /$ plant), higher wholesale prices will be needed, or perhaps "local" fresh markets can be developed similar to those that are now becoming available to North Carolina strawberry plasticulture growers who are shipping 'Camarosa' (SD type) to chain supermarkets in the region at prices that will often vary from
$\$ 10$ to $\$ 14$ per flat (equivalent to $\$ 2.76$ to $\$ 3.31 \mathrm{~kg}$ ).

In the initial stages, growers in the southern Appalachians may want to concentrate on development of direct market opportunities (selling by pick-your-own, ready-pick, roadside stands, and in farmers' markets). Along these lines, a grower near the Upper Mountain Research Station is currently marketing summer season 'Seascape' at $\$ 3.67 \mathrm{~kg}$ (1.67 lb) in a nearby farm market. Table 7 can be useful for evaluating the influence of varying yield and price level combinations on potential net revenue per kilogram. It can be seen from this table that a yield of $1 \mathrm{~kg} /$ plant is the breakeven yield (Safley et al., 2004) for a price point of $\$ 9.00$ flat (eight clamshells, $454 \mathrm{~g}$ ), which is equivalent to $\$ 2.48 \mathrm{~kg}$, or $\approx \$ 1.12 \mathrm{lb}$ (Table 7). Growers with average marketable yields of $1 \mathrm{~kg} / \mathrm{plant}$ and receive an average price of $\$ 12$ flat $(\$ 3.31 \mathrm{~kg}$ ) could potentially generate net revenue of $\$ 0.88 \mathrm{~kg}$, or $\$ 25,256$ ha $(\$ 10,225$ per acre) assuming a plant density of 28,700 plants/ha, and this compares favorably with the profit potential of a well-managed direct-market strawberry plasticulture operation in North Carolina (Safley et al., 2004).

Although we still have numerous "research questions" related to identifying optimum DN cultivars and production methods, including alternatives to methyl bromide fumigation (Welker, 2008) for growers in the southern Appalachians, our program's research in the near term is going to place

Table 5. The influence of day-neutral strawberry marketable yield on total cost per unit of production.

\begin{tabular}{|c|c|c|c|c|c|}
\hline$a$ & $b$ & $c$ & $d$ & $e$ & $f$ \\
\hline $\begin{array}{l}\text { Mkt. yield } \\
\text { plant }(\mathrm{kg})\end{array}$ & $\begin{array}{l}\text { Mkt. yield } \\
\text { ha }(\mathrm{kg})^{\mathrm{z}}\end{array}$ & $\begin{array}{l}\text { Preharvest } \\
\text { cost/ha }(\$)^{\mathrm{y}}\end{array}$ & $\begin{array}{c}\text { Harvest and } \\
\text { mkt. cost } / \text { ha }(\$)^{x}\end{array}$ & $\begin{array}{l}\text { Total cost } / \mathrm{ha} \\
\text { (\$) }(\text { col. } \mathrm{a}+\mathrm{b})\end{array}$ & $\begin{array}{c}\text { Total cost } / \mathrm{kg} \\
(\$)(\text { col. e/col. b) }\end{array}$ \\
\hline$\overline{0.4}$ & 11,480 & 27,068 & 17,679 & 44,747 & 3.90 \\
\hline 0.5 & 14,350 & 27,068 & 22,099 & 49,167 & 3.43 \\
\hline 0.6 & 17,220 & 27,068 & 26,519 & 53,587 & 3.11 \\
\hline 0.7 & 20,090 & 27,068 & 30,939 & 58,007 & 2.89 \\
\hline 0.8 & 22,960 & 27,068 & 35,358 & 62,426 & 2.72 \\
\hline 0.9 & 25,830 & 27,068 & 39,778 & 66,846 & 2.59 \\
\hline 1.0 & 28.700 & 27,068 & 44,198 & 71,266 & 2.48 \\
\hline 1.1 & 28,700 & 27,068 & 44,198 & 75,686 & 2.40 \\
\hline 1.2 & 31,570 & 27,068 & 53,038 & 80,106 & 2.33 \\
\hline 1.3 & 37,310 & 27,068 & 57,457 & 84,525 & 2.27 \\
\hline 1.4 & 40,180 & 27,068 & 61,877 & 88,945 & 2.21 \\
\hline 1.5 & 43,050 & 27,068 & 66,297 & 93,365 & 2.17 \\
\hline
\end{tabular}

${ }^{2}$ Calculation based on 28.7 thousand plants/ha: (column $\left.a\right) \times 28,700$.

yPreharvest cost does not vary with yield level (see Table 4).

${ }^{\times}$Harvest and marketing costs vary directly with yield level and are computed at $\$ 1.54 \mathrm{~kg}$ (see Table 4).

Table 6. Monthly harvest distribution for 'Everest' day-neutral strawberry potential revenues, Laurel Springs, $\mathrm{NC}^{\mathrm{z}}$.

\begin{tabular}{lcccr}
\hline Month & $\begin{array}{c}\text { Yield/plant } \\
(\mathrm{g})\end{array}$ & $\begin{array}{c}\text { Yield/ha } \\
(\mathrm{kg})^{\mathrm{y}}\end{array}$ & $\begin{array}{c}\text { Whl. price } \\
(\$)^{\mathrm{x}}\end{array}$ & $\begin{array}{c}\text { Gross rev. } \\
(\$)^{\mathrm{w}}\end{array}$ \\
\hline June & 29 & 840 & 1.33 & 1,117 \\
July & 575 & 16,488 & 1.32 & 21,764 \\
August & 619 & 17,778 & 1.68 & 29,880 \\
September & 47 & 1,336 & 1.79 & 2,391 \\
Total & 1,270 & 36,450 & 1.62 & 55,151 \\
\hline
\end{tabular}

${ }^{2}$ Data used in this analysis is based on average 'Everest' marketable yields on white plastic mulch from 2004 season, Laurel Springs, NC.

${ }^{y}$ Calculation based on 28.7 thousand plants/ha.

${ }^{x}$ USDA avg. monthly price, 2001 to 2005 (see Table 3)

${ }^{x}$ Potential gross revenue/ha and assuming that 'Everest' berries averaging $14.5 \mathrm{~g}$ in 2004 would be $100 \%$ marketable $(\approx 31$ berry count per $0.454-\mathrm{kg}$ clamshell) 
Table 7. Estimated net revenue for day-neutral strawberries for varying marketable yield levels and price levels.

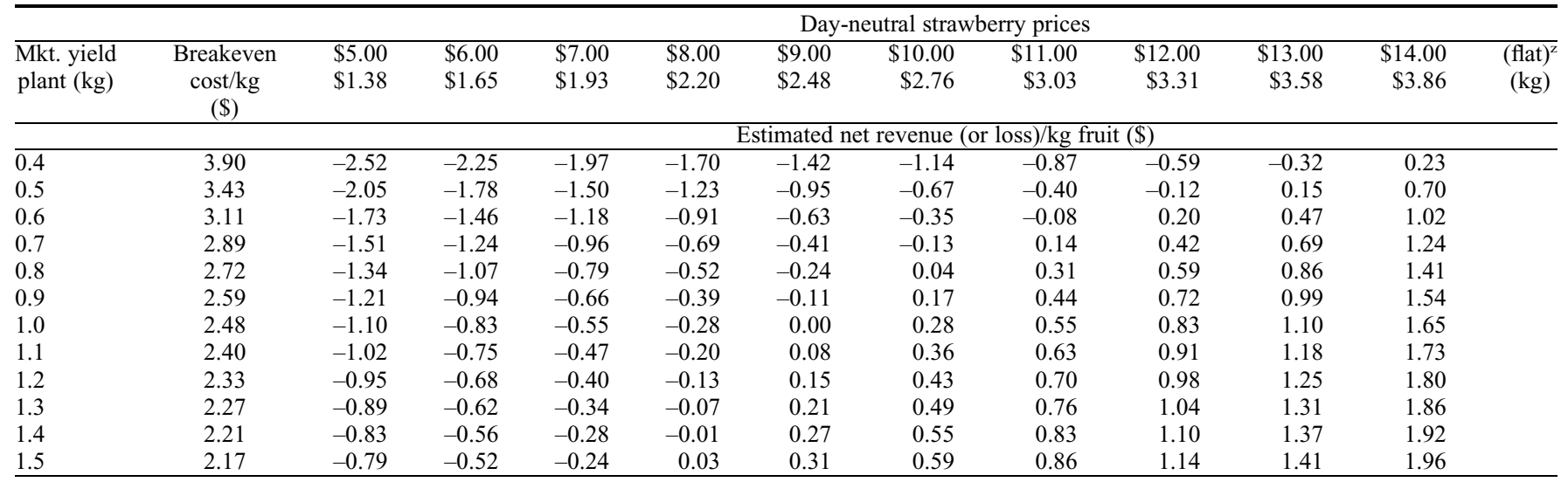

${ }^{2}$ Flat represents eight clamshells (454-g clamshell ${ }^{-1}$ ), or $3.62 \mathrm{~kg} / \mathrm{flat}^{-1}$.

more emphasis on test marketing projects in conjunction with the NC Specialty Crops Program, because we still do not have any direct knowledge of what consumers in this region will pay for locally grown DN strawberries in summer and fall. Will the prices be higher than wholesale prices paid for fresh market strawberries in the United States? If so, how much of a price premium can local growers anticipate? Along these same lines, a research team in the mid-Atlantic region, which has been working on DN strawberries under a SARE grant in the northeast since 2006, has recently reported on their future plans to test market mountain-grown DN fruit at some eastern Maryland chain supermarkets as "local produce" in hopes of establishing some baseline information about whether buyers will provide a price premium for locally grown strawberries in the offseason (Lantz et al., 2008).

\section{Literature Cited}

Boriss, H., H. Brunke, and M. Kreith. 2006. Commodity profile. Agricultural Issues Center, University of California, Mar. 2006.

Brown, B. 2005. A summary of the tobacco buyout. Tobacco buyout information. NC State University, Raleigh, NC. 22 July 2008. <http:// www.cals.ncsu.edu/advancement/tobaccobuyout/ buyoutbkgd_new.htm>.

Durner, E.F. 1999. Winter greenhouse strawberry production using conditioned plug plants. HortScience 34:615-616.
Fernandez, G. and J. Ballington. 2003. Double cropping of strawberries in an annual system using conditioned plug. Acta Hort. 614:547-552.

Kash, R. 2002. The new law of demand and supply. Doubleday, New York, NY.

Lantz, W., K. Demcheck, and H.S. Swartz. 2008. SARE research: Day neutral strawberries in the NE 2nd Annual Report. 22 July 2008. $<$ http://garrett.umd.edu/Agnr/Strawberryfolder/ StrawberrySAREReport2007\%20_2_.pdf $>$.

O'Dell, C. 1998. New options for field and greenhouse strawberries. Commercial Horticulture Newsletter, March-April, Virginia Cooperative Extension, Virginia Tech University. 22 July 2008. <http://www.ext.vt.edu/news/periodicals/ commhort/1998-04/1998-04-04.html>.

Pattison, J.A. and T.K. Wolf. 2007. Evaluating protected culture for season extension in small fruits. Progress Report to the Southern Region Small Fruits Consortium. 22 July 2008. <http:// www.smallfruits.org/SRSFCReserchFunding/ 2007.htm>.

Poling, E.B. 1993. Strawberry plasticulture in North Carolina: Part 1. Developing a competitive horticultural industry requires 'experts', not 'participatory groups'. HortTechnology 3:400-403.

Poling, E.B. 2004. Strawberry plasticulture-A possibility for local growers, p. 11-18. In: Childers N.F. (ed.). The strawberry: A book for growers, others. Meister Publications, Winter Park, FL.

Poling, E.B. and J.R. Ballington. 2006. Factors that will be important to the development of a profitable day-neutral strawberry production system for eastern growers. HortScience 41:913.

Poling, E.B. 2008. Antrhacnose on strawberry: Its etiology, epidemiology, and pathology, together with management strategies for strawberry nurseries: Introduction to the workshop. HortScience 43:59-65.

Pritts, M.P. and M.J. Kelly. 1995. Strawberry production in greenhouses. Misc. Publ., Dept. Fruit and Vegetable Science, Cornell Univ., Ithaca, NY.

Safley, C.D., E.B. Poling, M.K. Wohlgenant, O. Sydorovych, and R.F. Williams. 2004. Producing and marketing strawberries for directmarket operations. HortTechnology 14:16-26.

Serce, S. and J.F. Hancock. 2000. Sexual and vegetative performance of native and cultivated day-neutral strawberries under moderate and high temperatures. HortScience 35:424 (abstr.).

Sjulin, T. 2003. The North American small fruit industry 1903-2003. II. Contributions of public and private research in the past 25 years and a view to the future. HortScience 38:960-967.

Straw, R.A. 2005. Off-season strawberry production research proposal. 22 July $2008 .<\mathrm{http}: / /$ www.smallfruits.org/SRSFCReserchFunding/ Research04/Off-SeasonReport.pdf $>$.

Takeda, F. 1999. Out-of-season greenhouse strawberry production in soilless substrates. Adv. Strawberry Research 18:4-15.

Takeda, F. 2002. Out-of-season strawberry production in the eastern United States. Acta Hort. 567:569-572.

Vanden Heuvel, J.E. 2006. Breeding, growing, and marketing of repeat-fruiting small fruit cultivars for extended season (Part 2). HortScience 41:913 (abstr.).

Welker, R. 2008. Methyl bromide replacements for strawberries. In: Proc. of Georgia-South Carolina Strawberry Conference, Savannah, GA., 11-13 Jan. p. 84-88. 